\title{
Determination of Selected Metals and Nutritional Compositions of Pigeon Pea (Cajanus cajan) Cultivated in Wolaita Zone, Ethiopia
}

\author{
Mesfin Thomas Anjulo, Mesfin Bibiso Doda*, Camerun Kastro Kanido* \\ Department of Chemistry, College of Natural \& Computational Science, Wolita Sodo University, Sodo, Ethiopia \\ Email: *mefbab2009@gmail.com, ${ }^{*}$ castro2019came@gmail.com
}

How to cite this paper: Anjulo, M.T., Doda, M.B. and Kanido, C.K. (2021) Determination of Selected Metals and Nutritional Compositions of Pigeon Pea (Cajanus cajan) Cultivated in Wolaita Zone, Ethiopia. Journal of Agricultural Chemistry and Environment, 10, 37-56.

https://doi.org/10.4236/jacen.2021.101003

Received: November 2, 2020

Accepted: January 12, 2021

Published: January 15, 2021

Copyright $\odot 2021$ by author(s) and Scientific Research Publishing Inc. This work is licensed under the Creative Commons Attribution International License (CC BY 4.0).

http://creativecommons.org/licenses/by/4.0/

\begin{abstract}
This study was aimed to determine the level of selected metals and nutritional composition of pigeon pea seed collected from seven districts of Wolaita zone. A wet digestion procedure involving the use of mixtures of $(69 \%-72 \%)$ $\mathrm{HNO}_{3}$ and $(70 \%) \mathrm{HClO}_{4}$ at an optimum temperature and time duration was used to determine metals by using flame atomic absorption spectrometry. Kjeldahl digestion method, Soxhlet extraction and furnace were used to determine nutritional values of pigeon pea, and physicochemical properties of soils were assessed using standard methods. The results showed that the levels of concentration of metals in $\mathrm{mg} / \mathrm{kg}$ dry weight were ranged 105.17 to 144.07 for $\mathrm{K}, 8.95$ to 12.67 for $\mathrm{Mg}$, 7.74 to 12.27 for $\mathrm{Ca}, 0.247$ to 0.543 for $\mathrm{Fe}, 0.122$ to 0.313 for $\mathrm{Zn}, 0.061$ to 0.432 for $\mathrm{Mn}, 0.087$ to 0.134 for $\mathrm{Cu}$ and 0.0011 to 0.00196 for Cr. The proximate composition of pigeon pea was in the range of $19.28 \%$ to $25.79 \%$ for crude protein, $0.993 \%$ to $1.75 \%$ for crude fat, $3.75 \%$ to $5.31 \%$ for ash, $10.65 \%$ to $13.73 \%$ for moisture, $2.28 \%$ to $3.06 \%$ for fiber, $54.36 \%$ to $60.1 \%$ for carbohydrate and 326.8 to $345.23 \mathrm{Kcal}$ for energy. The $\mathrm{pH}$ of the soil was in the range from $\mathrm{pH} 5.09$ (strongly acidic) to 6.77 (slightly acidic), EC of the soil ranged from 0.047 to $0.14 \mathrm{dS} / \mathrm{m}$ (low), the soil OC level was from $1.6 \%$ to $2.42 \%$ (moderate), total Nitrogen was from $0.12 \%$ to $0.23 \%$ (low to moderate), the available Phosphorus content of the soil was from 6.82 to $13.52 \mathrm{mg} / \mathrm{kg}$ (low to moderate), CEC value of the soil was from 14.8 to $23.53 \mathrm{meq} / 100 \mathrm{~g}$ (moderate). The textural classes of soil were sandy clay loam for all sites except Abela abaya. The study confirmed that pigeon pea was a good source of proteins, carbohydrates, and selected metals such as $\mathrm{Mg}, \mathrm{K}$, $\mathrm{Ca}, \mathrm{Fe}, \mathrm{Zn}, \mathrm{Mn}, \mathrm{Cu}$, and $\mathrm{Cr}$. The concentration of metals and nutritional compositions of pigeon pea seed were found at a permissible level.
\end{abstract}




\section{Keywords}

Nutritional Value, Pigeon Pea, Selected Metals, Soil

\section{Introduction}

Pigeon pea (Cajanus cajan) domestically known as "Yergib ater", is an important legume grownup all over the tropics and subtropics for its fit for human consumption as a staple food. It is the preferred pulse crop in dryland areas where it is intercropped with cereals or other short-duration annuals. Dry grain, green pods, and fodder are the main products of pigeon pea [1]. It was believed that the origin of pigeon pea is either the North-Eastern part of Africa or India [2]. The cultivation of pigeon pea seed begun at least 3000 years ago. It is now a pantropical species particularly fitted to rain-fed agriculture in semi-arid areas because of its deep taproot, heat tolerance, and fast-growing habit [3]. Pigeon pea grows in places with a light-weight frost and in the areas where $20^{\circ} \mathrm{C}$ to $40^{\circ} \mathrm{C}$ temperature range [4]. It can nurture on soils with $\mathrm{pH} 5-7$ and from sands to heavy black clay soils [5].

In Africa, Cajanus cajan is a subsistence crop that some countries have been reported to export significant amounts [6]. Africa contributes $9.3 \%$ pigeon pea production of the world, which is inadequate compared to the contribution from India alone, which is $74 \%$ [7]. This perennial leguminous shrub withstands severe drought better than many legumes, which are because of its deep roots and osmotic adjustment in the leaves [8]. The supplementation of cereals with protein-rich legumes is considered one of the best solutions to alleviate protein-calorie malnutrition in the developing world [9]. Mostly, hunger and malnutrition are increasing as a result of population explosion, shortage of fertile land, and high food prices. Globally, it is the foremost cause of the ailment and the passing of millions of pregnant women and young children. Accordingly, the formulation of nutrient-rich food items from an economic and cheap source like pigeon pea offers an efficient alternative strategy to fight the problem of malnutrition efficiently [10].

In Ethiopia, there is high climate variability and therefore the occurrence of extreme events over recent times. The Ethiopian Institute of agricultural research has been conducted studies on problems of drought resistance, early maturing, and heat-tolerant crop species and varieties. Pigeon pea is one of the grain pulses chosen by the research institute for livelihood improvement to satisfy the present nutrient need of poor and vulnerable people at large [11]. Dryland legumes are believed to offer enormous opportunities for reducing food insecurity and poverty in the semi-arid tropics as a result of their adaptability to such conditions [12]. It also plays a significant role in sustaining the degree of nutrients in soil productivity by fixing atmospheric nitrogen for crop productivity, adding organic matter and micronutrients, and breaking hard plough pan with its long taproots for crop productivity [9]. Pigeon pea has a high tolerance 
to environmental stresses and has high biomass productivity [13].

Pigeon pea is a good source of essential metals such as $\mathrm{Mg}, \mathrm{Ca}, \mathrm{Fe}, \mathrm{K}, \mathrm{Na}, \mathrm{Mn}$, $\mathrm{Cr}$, and $\mathrm{Zn}$. Metals like $\mathrm{Cu}, \mathrm{Cr}, \mathrm{Fe}, \mathrm{Zn}$, and $\mathrm{Mn}$ are essential for animals and human beings because they play a vital role in different metabolic functions, enzymatic activities, sites for receptors, hormonal functions, and protein transport at specific concentrations [14] [15] [16]. However, excess intake of such elements can cause chronic toxicity [17].

Research and development efforts have supported the release and commercialization of a substantial number of improved varieties of major lowland pulses in Ethiopia. National statistics on area production, and consumption for many decades on pulse crops compared to pigeon pea, whereas pigeon pea has no records since 2014 [18]. There is no documented information on the composition of macro and micronutrient and the nutritional value of pigeon pea grown in the Wolaita zone. Hence, the objective of this study was to determine the distribution pattern of selected metals and nutritional compositions of pigeon pea cultivated in the Wolaita zone, Ethiopia.

\section{Materials and Methods}

\subsection{Description of Sampling Locations}

The study was conducted in the Wolaita zone, South Ethiopia. The area is found at South Central Ethiopia between 6.40N - 6.90N latitude and 37.40E - 38.20E longitude and is located at $390 \mathrm{~km}$ south of Addis Ababa. The zone has a total area of $4541 \mathrm{~km}^{2}$ and is composed of 16 districts and 6 registered towns. Its altitude ranges from 700 - $2900 \mathrm{~m}$ above sea level. The study area encloses three agro-climatic zones, Kolla (lowland $<1500 \mathrm{~m}$ ), Woina-Dega (mid-altitude 1500 - $2300 \mathrm{~m}$ ) and Dega (high land $>2300 \mathrm{~m}$ ) with most of the area lies within the mid-altitude zone [19].

\subsection{Apparatus and Instruments}

Polyethylene bag, glass bottles, Electronic miller (Foss Knife tec1095, USA, Digital analytical balance, round bottom flasks, Kjeldahl (UK) apparatus, hot plate, measuring cylinders, pipettes, micropipettes (Dragon med, 1 - $10 \mu \mathrm{L}, 100-1000$ $\mu \mathrm{L}$ ), acid reagents and metal standard solutions. Porcelain crucible, SG-deionizer (Germany, model; SG-2000), Soxhlet apparatus, rotator evaporator, water bath (UK, model; RE200) were used for sample collection and preparations. Flame atomic absorption spectrophotometer (FAAS) was used for the metal analysis. The $\mathrm{pH}$ meter to determine $\mathrm{pH}$ of the soil and conductivity meter was used to measure electrical conductivity.

\subsection{Chemicals and Reagents}

$\mathrm{HNO}_{3}(69 \%-72 \%), \mathrm{HClO}_{4}\left(70 \%\right.$, Analar BDH, England), and $30 \% \mathrm{H}_{2} \mathrm{O}_{2}$ Scharlau, European Union, $\mathrm{LaCl}_{2} \cdot 6 \mathrm{H}_{2} \mathrm{O}$ (Aldrich, USA), all the reagents used were of analytical grade. Stock standard solutions containing $1000 \mathrm{mg} / \mathrm{l}$, in $2 \% \mathrm{HNO}_{3}$, of 
the elements $\mathrm{K}, \mathrm{Ca}, \mathrm{Mg}, \mathrm{Fe}, \mathrm{Zn}, \mathrm{Mn}, \mathrm{Cu}, \mathrm{Cr}$, and $\mathrm{Cd}$ was used for the preparation of calibration standards and in the spiking experiments. Deionized water was used throughout the experiment. Petroleum ether $40 \%-60 \%$ was used for fat extraction and Boric acid, $\mathrm{NaOH}$, selenium oxide, methyl red, $0.1 \mathrm{~N} \mathrm{HCl}$, methyl blue indicator, and $\mathrm{K}_{2} \mathrm{SO}_{4}, \mathrm{CuSO}_{4}$, and $\mathrm{SeO}_{2}$ catalysts mixtures were used for total nitrogen content analysis in the sample for protein determination. The mixture of $\mathrm{HCl}, \mathrm{HNO}_{3}$ (3:1 ratios), and $30 \% \mathrm{H}_{2} \mathrm{O}_{2}$ was used for the digestion of soil samples in macronutrient and micronutrient determination.

\subsection{Sample Collection and Preparation}

The pigeon pea seed (Cajanus cajan) samples were collected from different localities based on their availability and knowledge of the society regarding their uses. Accordingly, seven sample sites Sodo zuria, Humbo, Abela abaya, Damot woyde, Hobicha from districts, and Tebela and Sodo from town administrations were selected. Triplicate samples of pigeon pea seed from seven sites $(3 \times 7=21)$ were collected in the Wolaita zone. The collected samples were used for the determination of selected metals and nutritional values of pigeon pea seed.

\subsection{Soil Analysis}

\subsubsection{Soil Sampling and Preparation}

Surface soil samples $(0-20 \mathrm{~cm})$ was collected using auger from different points in a plot of seven different sites of five districts (Abela abaya, Humbo, Hobicha, Sodo zuria, Damot Woyde) and two town administrations (Tebela and Sodo). The soil samples collected from the same plots where pigeon pea seed samples were collected. A total of seven Composite soil samples were collected from the study areas and prepared after thoroughly mixing (homogenizing) the sub-samples of each plot in a plastic bowl. Soils were air-dried ground and mixed thoroughly and passed through a $2 \mathrm{~mm}$ sieve for most parameters. Laboratory analysis was conducted to determine the major soil physical and chemical parameters [20].

\subsubsection{Physicochemical Properties of Soil}

Soil $\mathrm{pH}$ was measured potentiometrically in $\mathrm{H}_{2} \mathrm{O}$ and $1 \mathrm{M} \mathrm{KCl}$ solution at the ratio of 1:2.5 for soil: $\mathrm{H}_{2} \mathrm{O}$ and soil: $\mathrm{KCl}$ solutions using a combined glass electrode $\mathrm{pH}$ meter [21]. Electrical Conductivity (EC) was measured in water as soil to water ratio of 1:5 using a conductivity meter [22]. Soil organic carbon was determined using the Walkley-Black method [23]. Available P was determined by the Olsen method [24]. Total nitrogen (TN) was determined by the Kjeldahl wet digestion and distillation method [25]. The texture of the soil was determined by the hydrometer method after the dispersion of the soil with sodium Hexa Metaphosphate [26]. The cation exchange capacity (CEC) of the soil was determined using the micro-Kjeldahl procedure [25].

2.5.3. Determination of Metal Levels in the Pigeon Pea Samples by FAAS A wet digestion method was used for metal ( $\mathrm{Ca}, \mathrm{K}, \mathrm{Cu}, \mathrm{Fe}, \mathrm{Mg}, \mathrm{Mn}, \mathrm{Cd}, \mathrm{Zn}$, and 
$\mathrm{Cr}$ ) analysis. The various acid and flux treatments were carried out at high temperatures in specially designed vessels that help to minimize contamination of the sample with substances in the air, adsorption onto the vessel walls, volatilization, and co-extraction [27].

\subsubsection{Methods for Proximate Analysis}

The proximate analysis (carbohydrate, fats, protein, moisture, fiber, and ash) of pigeon pea (Cajanus cajan) sample was determined by using the AOAC, 2000 method. Carbohydrate was determined by difference $[100-$ (protein + fat + moisture + ash + fiber)]. The nitrogen value was determined by the Micro-kjeldhal method. The nitrogen value was converted to protein by multiplying to a factor of 6.25. The moisture, ash, and fiber were determined using the weight difference method while the determination of crude fat content of pigeon pea sample was done using the Soxhlet extraction method [28].

\section{Results and Discussions}

\subsection{Optimization of the Working Procedure}

To prepare a clear and colorless sample solution that was suitable for the analysis using FAAS, different working procedures for the digestion of plant samples assessed using mixtures of $\mathrm{HNO}_{3}$ and $\mathrm{HClO}_{4}$ acids by varying parameters such as the volume of the acid mixture, digestion time, and digestion temperature [29] [30]. As can be seen in Table 1 trial No. 5, consumed smaller reagent (acid) volume, smaller digestion time, and a colorless solution with no residue was obtained were chosen as the working conditions.

\subsection{Calibration of Instruments}

Standard solutions containing $1000 \mathrm{mg} / \mathrm{l}$ were used for preparing intermediate standard solutions $(10 \mathrm{mg} / \mathrm{l})$ in a $100 \mathrm{~mL}$ volumetric flask. As the values were given in Table 2 appropriate working standards were prepared for each of the metal solutions by serial dilution of the intermediate solutions using deionized water. Calibration curves were plotted with five points for each of the standard

Table 1. Optimization of parameters for wet digestion of pigeon pea samples (Reagent types and volumes, temperature and time attempted during optimization).

\begin{tabular}{cccccc}
\hline Trial No. & Reagent used & $\begin{array}{c}\text { Reagent volume } \\
(\mathrm{ml})\end{array}$ & $\begin{array}{c}\text { Temperature } \\
\left({ }^{\circ} \mathrm{C}\right)\end{array}$ & $\begin{array}{c}\text { Digestion } \\
\text { time (h) }\end{array}$ & Observation \\
\hline 1 & $\mathrm{HNO}_{3}: \mathrm{HClO}_{4}$ & $5: 1$ & 150 & $1: 30$ & Light yellow \\
2 & $\mathrm{HNO}_{3}: \mathrm{HClO}_{4}$ & $4: 2$ & 180 & $1: 50$ & Deep yellow \\
3 & $\mathrm{HNO}_{3}: \mathrm{HClO}_{4}$ & $3: 3$ & 180 & $2: 10$ & Clear yellow \\
4 & $\mathrm{HNO}_{3}: \mathrm{HClO}_{4}$ & $4: 1$ & 210 & $2: 30$ & Pale yellow \\
5 & $\mathrm{HNO}_{3}: \mathrm{HClO}_{4}^{*}$ & $3: 2^{*}$ & $240^{*}$ & $2: 50^{*}$ & Clear colorless \\
6 & $\mathrm{HNO}_{3}: \mathrm{HClO}_{4}$ & $4: 2$ & 270 & $3: 10$ & Almost clear \\
\hline
\end{tabular}

*Indicates optimum condition. 
of the selected metal using absorbance against concentrations ( $\mathrm{mg} / \mathrm{l})$ and the correlation coefficients of the calibration curves were $>0.997$. This confirmed a very good positive correlation between the change in absorbance and concentration.

\subsection{Method Detection Limit}

The method detection limit for the analysis of metals using FAAS in pigeon pea seed samples was determined using reagent blank. Seven blank samples were digested following the same procedure as the samples and each of the blank samples was analyzed for metal concentrations of $\mathrm{Cu}, \mathrm{Cd}, \mathrm{K}, \mathrm{Mg}, \mathrm{Ca}, \mathrm{Zn}, \mathrm{Mn}, \mathrm{Fe}$, and $\mathrm{Cr}$ by FAAS. The standard deviation for each element was calculated from blank measurements to determine the method detection limit. Which usually corresponds to three times the standard deviation of the blank (Limit of detection $=3 \mathrm{SD}$, where $\mathrm{SD}=$ standard deviation of the blanks) [31]. The result showed that the method detection limit is less than the results of real samples for detected metals and greater than those of not detected metals. From Table 3, the method detection limits estimated were greater than the instrument detection limit for all metals in pigeon pea samples.

\subsection{Validation of Optimized Procedure (Recovery)}

The validity of the analytical procedures and efficiency of the atomic absorption spectrophotometer used for sample treatment and analysis was tested by spiking experiment in a selected sample. For this purpose standard solution of $1000 \mathrm{mg} / \mathrm{l}$

Table 2. Concentration of the standard solutions for FAAS instrument Calibration.

\begin{tabular}{cccc}
\hline Metals & $\begin{array}{c}\text { Concentration of the } \\
\text { standards in ( } \mathbf{m g} / \mathbf{l})\end{array}$ & Correlation coefficients & $\begin{array}{c}\text { Equation for calibration } \\
\text { curve }(\mathrm{A}=\mathrm{mC}+\mathrm{b})\end{array}$ \\
\hline $\mathrm{Ca}$ & $5,10,15,20,25$ & $\mathrm{~A}=0.1159 \mathrm{C}+0.0137$ \\
$\mathrm{Mg}$ & $5,10,15,20,25$ & $\mathrm{~A}=0.177 \mathrm{C}+0.2276$ \\
$\mathrm{~K}$ & $0.065,0.41,0.785,1.11,1.57$ & 0.998 & $\mathrm{~A}=0.1676 \mathrm{C}-0.0858$ \\
$\mathrm{Fe}$ & $1,2.5,5,8,10$ & $\mathrm{~A}=0.028 \mathrm{C}-0.0048$ \\
$\mathrm{Mn}$ & $0.5,1.5,3,5,9$ & $\mathrm{~A}=0.1358 \mathrm{C}+0.0872$ \\
$\mathrm{Zn}$ & $0.25,0.5,1.0,1.5,2.0$ & 0.998 & $\mathrm{~A}=0.333 \mathrm{C}-0.0126$ \\
$\mathrm{Cu}$ & $0.15,0.35,0.61,0.84,1.5$ & 0.999 & $\mathrm{~A}=0.0837 \mathrm{C}+0.0169$ \\
$\mathrm{Cr}$ & $0.05,0.5,1.0,1.5,2.0$ & 0.9999 & $\mathrm{~A}=0.01 \mathrm{C}+0.0017$ \\
$\mathrm{Cd}$ & $0.5,1.0,1.5,2.0,2.5$ & 0.9997 & $\mathrm{~A}=0.292 \mathrm{C}+0.056$ \\
\hline
\end{tabular}

$\mathrm{A}=$ Absorbance, $\mathrm{C}=$ Concentration in $\mathrm{mg} / \mathrm{l}, \mathrm{m}=$ The slope, $\mathrm{b}=$ Intercept.

Table 3. Detection limits for the analysis of pigeon pea samples by FAAS.

\begin{tabular}{cccccccccc}
\hline Metals & $\mathrm{Ca}$ & $\mathrm{Mg}$ & $\mathrm{K}$ & $\mathrm{Fe}$ & $\mathrm{Mn}$ & $\mathrm{Zn}$ & $\mathrm{Cu}$ & $\mathrm{Cr}$ & $\mathrm{Cd}$ \\
\hline IDL (ppm) & 0.001 & 0.001 & 0.001 & 0.003 & 0.001 & 0.005 & 0.001 & 0.001 & 0.001 \\
MDL (mg/Kg) & 0.002 & 0.005 & 0.003 & 0.01 & 0.01 & 0.007 & 0.004 & 0.0011 & 0.002 \\
\hline
\end{tabular}

$\mathrm{IDL}=$ Instrument Detection Limit, $\mathrm{MDL}=$ Method Detection Limit. 
was used and intermediate standards of $10 \mathrm{mg} / \mathrm{l}$ were prepared. The spiked and non-spiked samples were digested and analyzed in similar conditions using an optimized procedure for sample analysis.

As presented in Table 4, the results of the percent recoveries for all the metals in the analyzed pigeon pea sample were found within $100 \pm 10$ percent (90 105.8 ) and the RSD values ranged between $1.3 \%-8.2 \%$. This indicates that contamination was not a problem in the digestion procedure and the recovery results were in good agreement with the acceptable values [32].

\subsection{Determination of Physicochemical Properties of Soil}

\section{Soil texture}

As shown in Table 5, the particle size division of the soil types: \% clay, \% silt, and \% sand was ranged from $24.7-48.6,13.1-25$, and $28.2-59.8$, respectively. The textural class of the soil was sandy clay loam in all the studied sites except Abela Abaya (AA). The textural class of the soil of AA was clay loam. This soil, therefore, has the potential to hold more water within the particles and suitable for plant growth due to the presence of a relatively high percentage of clay. Sandy soils contain low organic matter and retain little water and, therefore, percolation of water through it is high while clay soil contains high organic matter, capable to resist water and wind erosion of the soil, high cation exchanging capacity and $\mathrm{pH}$ buffering capacity [33].

\section{$\mathrm{pH}$}

The $\mathrm{pH}$ of studied soil samples was found to be in the range of 5.09 to 6.77 . The highest $\mathrm{pH}$ value (6.77) was obtained in the soils of AA which were slightly acidic compared with the lowest value of soils of Sodo zuria (SZ) (5.09). There were variations in soil $\mathrm{pH}$ levels from the soil samples analyzed. The lower $\mathrm{pH}$ of $\mathrm{SZ}$ was due to the leaching of basic nutrients $\mathrm{Ca}, \mathrm{Mg}$ from the soil, and replacement of acidic elements such as $\mathrm{Al}^{3+}, \mathrm{Fe}^{2+}$ [34]. According to Jones (2003), the $\mathrm{pH}$ ranges of the soils in studied areas were from strongly acidic to slightly acidic

Table 4. Recovery test results of metals for pigeon pea spike sample.

\begin{tabular}{cccccc}
\hline Metals & $\begin{array}{c}\text { Conc. in sample } \\
(\mathrm{mg} / \mathbf{1 0 0 \mathrm { g } )}\end{array}$ & $\begin{array}{c}\text { Amount added } \\
(\mathrm{ppm})\end{array}$ & $\begin{array}{c}\text { Conc. in spiked } \\
\text { sample (mg/100g) }\end{array}$ & Recovery (\%) & RSD (\%) \\
\hline $\mathrm{K}$ & $123.6 \pm 2.4$ & 61.8 & $184.1 \pm 3.5$ & $97.8 \pm 1.8$ & 1.83 \\
$\mathrm{Mg}$ & $10.2 \pm 0.12$ & 5.1 & $15.6 \pm 0.53$ & $105.8 \pm 4.2$ & 3.97 \\
$\mathrm{Ca}$ & $9.7 \pm 0.19$ & 4.85 & $14.1 \pm 1.1$ & $90.7 \pm 2.5$ & 2.2 \\
$\mathrm{Fe}$ & $0.36 \pm 0.04$ & 0.18 & $0.55 \pm 0.06$ & $105.6 \pm 7.3$ & 6.9 \\
$\mathrm{Zn}$ & $0.23 \pm 0.01$ & 0.11 & $0.33 \pm 0.03$ & $90.9 \pm 1.2$ & 1.3 \\
$\mathrm{Mn}$ & $0.2 \pm 0.013$ & 0.1 & $0.29 \pm 0.01$ & $90 \pm 6.7$ & 7.4 \\
$\mathrm{Cu}$ & $0.1 \pm 0.005$ & 0.05 & $0.147 \pm 0.08$ & $94 \pm 2.9$ & 3.1 \\
$\mathrm{Cr}$ & $0.002 \pm 0.0001$ & 1.0 & $1.001 \pm 0.07$ & $99.9 \pm 8.2$ & 8.2 \\
$\mathrm{Cd}$ & $\mathrm{ND}$ & $\mathrm{ND}$ & $\mathrm{ND}$ & $\mathrm{ND}$ & $\mathrm{ND}$ \\
\hline
\end{tabular}


in nature [35]. The higher acidity of the soils for SZ was mainly due to the leaching of some basic cations [36]. Soil acidity affects the process of other nutrient transformations, solubility, or plant availability of many plant essential nutrients [37].

\section{Soil electrical conductivity}

As displayed in Table 5, the electrical conductivity (EC) of the soils were ranged from $0.047-0.14 \mathrm{dS} / \mathrm{m}$. Deshmukh (2012) reported that the EC value for good soil rated less than $1 \mathrm{dS} / \mathrm{cm}$. Hence, all soils under investigation were rated as low EC values [38]. The low EC value due to diverse anthropogenic and natural activities including leaching of exchangeable bases, acid rains, organic materials decomposition, use of commercial fertilizers, and other farming practices [33].

\section{Cation exchange capacity}

The results in Table 5 confirmed that the cation exchange capacity (CEC) of the soil was in the range of 14.8 to $23.53 \mathrm{cmol} / \mathrm{kg}$ of soil. The uppermost value was observed at AA district whereas, the lowermost was recorded from SZ (14.8 $\mathrm{cmol} / \mathrm{kg}$ ) districts. According to Landon (1991), the CEC of the soils of the study areas rated as moderate [39]. The CEC of soil is highly influenced by clay content and organic matter of the soil. Soil with higher clay content and organic matter has higher CEC [40]. The relatively low CEC of the Sodo zuria district may be due to the highest sand fraction and the lowest clay fractions of the soil [41].

\section{Soil organic carbon}

As depicted in Table 5, the organic carbon (OC) of soil ranged from 1.6 to 2.42. The highest value was found in AA (2.42) and the lowest value was observed in SZ (1.6). According to the rating suggested by Tekalign et al. (1991), the soil OC contents of the study area was the moderate range [42]. Soils relatively higher in clay content tend to stabilize and retain more OM than soils with low clay content [43].

\section{Soil total nitrogen (TN)}

The TN of the soil sample ranged from 0.12 to 0.23 as shown in Table 5 . The highest results were observed for AA (0.23) and the lowest records for SZ (0.12). According to Chowdhury et al. (2011), the soil total nitrogen of the study area was ordered from low to moderate [44]. Low total nitrogen was recorded in all four sites except AA (0.23\%), Ho (0.21), and DW (0.185) (moderate). The results were in harmony with the findings of Wakene and Heluf (2003) who reported that intensive and continuous cultivation forced oxidation of $\mathrm{OC}$ and thus resulted in a reduction of total $\mathrm{N}$ [45].

\section{Available Phosphorus}

The available $\mathrm{P}$ content of the soil revealed in Table 5 was ranged from 6.82 to $13.52 \mathrm{mg} / \mathrm{kg}$. A relatively higher percentage of available phosphorous was observed in the soil of the AA (13.52) district and the lowest available phosphorus was found in SZ (6.82). The low availability of Phosphorus is due to the fact that 
Table 5. The physicochemical properties of soil.

\begin{tabular}{|c|c|c|c|c|c|c|c|c|c|c|}
\hline \multirow{2}{*}{ Site } & \multirow{2}{*}{$\mathrm{pH}$} & \multirow{2}{*}{$\% \mathrm{EC}$} & \multirow{2}{*}{$\%$ CEC } & \multirow{2}{*}{$\%$ OC } & \multirow{2}{*}{$\mathrm{TN}$} & \multirow{2}{*}{ Av. $P$} & \multicolumn{3}{|c|}{ Texture of soil } & \multirow{2}{*}{$\begin{array}{c}\text { Textural } \\
\text { class }\end{array}$} \\
\hline & & & & & & & $\%$ clay & $\%$ Silt & $\%$ Sand & \\
\hline $\mathrm{AA}$ & 6.77 & 0.14 & 23.53 & 2.42 & 0.23 & 13.52 & 48.6 & 23.6 & 28.2 & $\mathrm{CL}$ \\
\hline DW & 6.09 & 0.12 & 19.23 & 2.05 & 0.185 & 8.29 & 24.7 & 25 & 50.3 & SCL \\
\hline HW & 5.61 & 0.07 & 21.3 & 2.26 & 0.15 & 11.37 & 25.5 & 19.1 & 55.4 & SCL \\
\hline $\mathrm{ST}$ & 5.25 & 0.05 & 17.3 & 1.77 & 0.14 & 7.58 & 29.3 & 14.7 & 56 & SCL \\
\hline $\mathrm{SZ}$ & 5.09 & 0.047 & 14.8 & 1.6 & 0.12 & 6.82 & 27.1 & 13.1 & 59.8 & SCL \\
\hline Ho & 6.36 & 0.116 & 18.07 & 1.71 & 0.21 & 10.27 & 28 & 19.8 & 52.2 & SCL \\
\hline $\mathrm{TT}$ & 5.57 & 0.09 & 19.6 & 2.24 & 0.16 & 8.2 & 32 & 13.4 & 54.6 & SCL \\
\hline
\end{tabular}

AA = Abela Abaya, DW = Damot Woyde, $\mathrm{HW}=$ Humbo Woreda, $\mathrm{ST}=$ Sodo Town, $\mathrm{SZ}=$ Sodo Zuria, Ho = Hobicha, TT $=$ Tebela Town.

it readily forms insoluble complexes with a cation such as aluminum ( $\mathrm{Al}$ ) and iron (Fe) under acidic soil condition [46]. According to Chowdhury et al. (2011), the available phosphorus content of the current study was low to moderate [44]. This may be due to past fertilization, $\mathrm{pH}$, organic matter, texture, and various soil management and agronomic practices and the low availability might be due to leaching, soil erosion, and crop harvest [47] [48].

\subsection{Determination of Selected Metals in Pigeon Pea Seed}

The pigeon pea samples were analyzed for selected metals ( $\mathrm{Ca}, \mathrm{Mg}, \mathrm{K}, \mathrm{Fe}, \mathrm{Mn}$, $\mathrm{Zn}, \mathrm{Cu}, \mathrm{Cr}$, and $\mathrm{Cd}$ with FAAS. The results showed that the concentrations of the selected metals ( $\mathrm{Ca}, \mathrm{Mg}, \mathrm{K}, \mathrm{Fe}, \mathrm{Mn}, \mathrm{Zn}, \mathrm{Cu}$, and $\mathrm{Cr}$ ) in pigeon pea seeds of seven sites were detected. The samples had a variable composition of each analyte metals with different concentration ranges among different sites in pigeon pea samples except for $\mathrm{Cd}$ which was below the detection limit. Metals were measured in the pigeon pea samples utilizing the FAAS instrument by the external calibration method. The concentration of metals in pigeon pea samples varied in the order of $\mathrm{K}>\mathrm{Mg}>\mathrm{Ca}>\mathrm{Fe}>\mathrm{Zn}>\mathrm{Mn}>\mathrm{Cu}>\mathrm{Cr}$ (Table 6, Table 7 and Figure 1).

\section{Levels of Metals in the Pigeon Pea Samples}

Potassium: As depicted in Table 6, the potassium concentration was ranged (105.17 - $144.07 \mathrm{mg} / \mathrm{Kg})$. The highest concentration was observed at AA (144.07 $\mathrm{mg} / \mathrm{Kg})$ and the least mean concentration was recorded at $\mathrm{SZ}(105.17 \mathrm{mg} / \mathrm{Kg})$. These could be attributed to different factors such as geographical and climatic variation, differences in physicochemical nature of the soil, and differences in the agricultural practices and inputs used for plant growth [16]. The mean concentration of metal uptake by plants increases as the levels of these metals increase in the soil environment [49]. Nwokolo (2010), reported the mean concentration of potassium in pigeon pea was $125 \mathrm{mg} / \mathrm{Kg}$ [50], Rajni and Vikas, 2016 reported $110.4 \mathrm{mg} / \mathrm{Kg}$ [51], which were in good agreement with the results 
Table 6. The (K, Mg, mean concentration of metals $\mathrm{Ca}, \mathrm{Fe})$ with in pigeon pea locations.

\begin{tabular}{ccccc}
\hline \multirow{2}{*}{ Districts } & \multicolumn{4}{c}{ Metals } \\
\cline { 2 - 5 } & $\mathrm{K}$ & $\mathrm{Mg}$ & $\mathrm{Ca}$ & $\mathrm{Fe}$ \\
\hline AA & $144.067^{\mathrm{a}} \pm 2.32$ & $12.67^{\mathrm{a}} \pm 0.04$ & $12.27^{\mathrm{a}} \pm 0.12$ & $0.247^{\mathrm{e}} \pm 0.03$ \\
DW & $128.97^{\mathrm{b}} \pm 3.4$ & $11.37^{\mathrm{b}} \pm 0.07$ & $11.27^{\mathrm{b}} \pm 0.5$ & $0.278^{\mathrm{cd}} \pm 0.09$ \\
HW & $121.40^{\mathrm{c}} \pm 2.07$ & $10.54^{\mathrm{c}} \pm 0.17$ & $8.87^{\mathrm{c}} \pm 0.08$ & $0.378^{\mathrm{c}} \pm 0.013$ \\
ST & $114.87^{\mathrm{d}} \pm 2.06$ & $9.20^{\mathrm{e}} \pm 0.08$ & $7.74^{\mathrm{d}} \pm 0.2$ & $0.465^{\mathrm{b}} \pm 0.013$ \\
SZ & $105.17^{\mathrm{e}} \pm 3.19$ & $8.95^{\mathrm{f}} \pm 0.03$ & $7.35^{\mathrm{d}} \pm 0.18$ & $0.543^{\mathrm{a}} \pm 0.03$ \\
Ho & $128.07^{\mathrm{b}} \pm 0.65$ & $11.26^{\mathrm{b}} \pm 0.21$ & $11.2^{\mathrm{b}} \pm 0.14$ & $0.283^{\mathrm{ed}} \pm 0.02$ \\
TT & $122.87^{\mathrm{c}} \pm 1.4$ & $10.1^{\mathrm{d}} \pm 0.02$ & $9.21^{\mathrm{c}} \pm 0.08$ & $0.314^{\mathrm{d}} \pm 0.04$ \\
LSD & 4.08 & $0 . .19$ & 0.41 & 0.04 \\
CV & 1.89 & 1.04 & 2.38 & 5.97 \\
\hline
\end{tabular}

${ }^{*}$ Means with the same letter are not significant, LSD $=$ Least significance difference, $\mathrm{CV}=$ Coefficient of Variance, AA = Abela Abaya, DW $=$ Damot Woyde, HW $=$ Humbo Woreda, $\mathrm{ST}=$ Sodo Town, $\mathrm{SZ}=$ Sodo Zuria, Ho $=$ Hobicha, TT $=$ Tebela Town.

Table 7. The mean concentration of metals $(\mathrm{Zn}, \mathrm{Mn}, \mathrm{Cu}, \mathrm{Cr})$ with in pigeon pea locations.

\begin{tabular}{cccccc}
\hline \multirow{2}{*}{ Districts } & \multicolumn{5}{c}{ Metals } \\
\cline { 2 - 6 } & $\mathrm{Zn}$ & $\mathrm{Mn}$ & $\mathrm{Cu}$ & $\mathrm{Cr}$ & $\mathrm{Cd}$ \\
\hline AA & $0.12^{\mathrm{f}} \pm 0.001$ & $0.06^{\mathrm{d}} \pm 0.04$ & $0.08^{\mathrm{d}} \pm 0.002$ & $0.0011^{\mathrm{e}} \pm 0.0002$ & $\mathrm{ND}$ \\
DW & $0.22^{\mathrm{d}} \pm 0.004$ & $0.12^{\mathrm{cd}} \pm 0.08$ & $0.09^{\mathrm{cb}} \pm 0.002$ & $0.0014^{\mathrm{dc}} \pm 0.0008$ & $\mathrm{ND}$ \\
HW & $0.23^{\mathrm{d}} \pm 0.019$ & $0.26^{\mathrm{b}} \pm 0.02$ & $0.10^{\mathrm{b}} \pm 0.006$ & $0.0015^{\mathrm{c}} \pm 0.0001$ & $\mathrm{ND}$ \\
ST & $0.29^{\mathrm{b}} \pm 0.004$ & $0.30^{\mathrm{b}} \pm 0.006$ & $0.13^{\mathrm{a}} \pm 0.02$ & $0.0017^{\mathrm{b}} \pm 0.0003$ & $\mathrm{ND}$ \\
SZ & $0.31^{\mathrm{a}} \pm 0.007$ & $0.43^{\mathrm{a}} \pm 0.01$ & $0.12^{\mathrm{a}} \pm 0.01$ & $0.0019^{\mathrm{a}} \pm 0.0002$ & $\mathrm{ND}$ \\
Ho & $0.20^{\mathrm{e}} \pm 0.02$ & $0.13^{\mathrm{c}} \pm 0.03$ & $0.09^{\mathrm{cb}} \pm 0.001$ & $0.0016^{\mathrm{bc}} \pm 0.0003$ & $\mathrm{ND}$ \\
TT & $0.25^{\mathrm{c}} \pm 0.008$ & $0.15^{\mathrm{c}} \pm 0.03$ & $0.1^{\mathrm{cb}} \pm 0.001$ & $0.0013^{\mathrm{d}} \pm 0.0002$ & $\mathrm{ND}$ \\
LSD & 0.018 & 0.073 & 0.013 & 0.0001 & ND \\
CV & 4.41 & 6.5 & 7.11 & 2.004 & ND \\
\hline
\end{tabular}

${ }^{*}$ Means with the same letter are not significant.
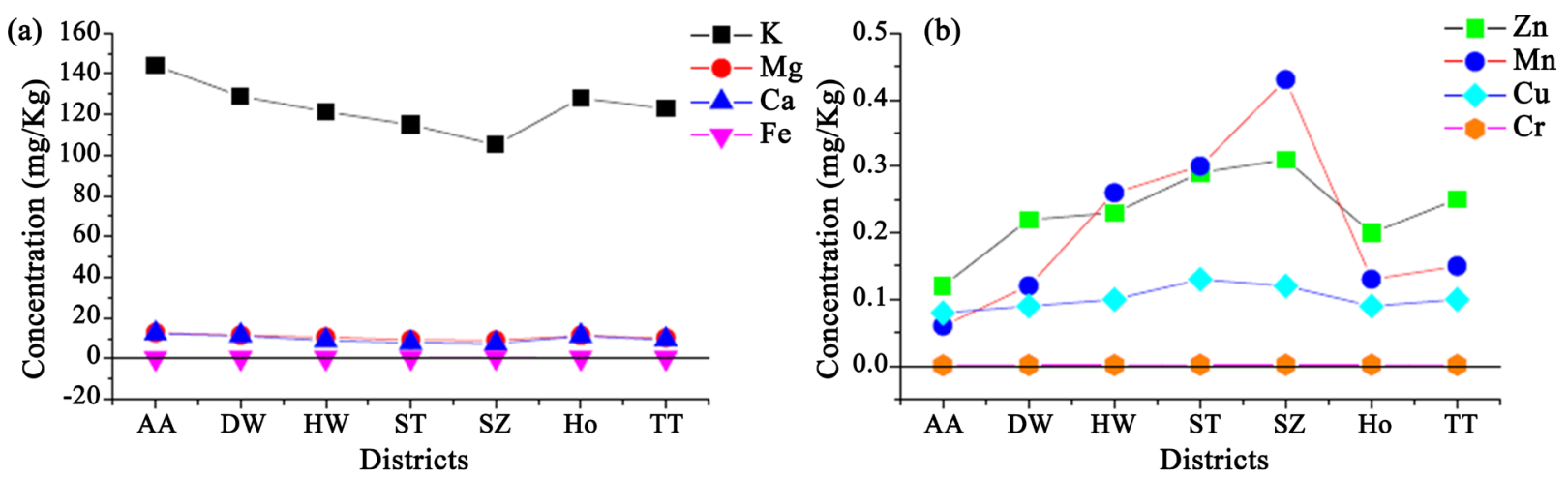

Figure 1. Distribution of metals in pigeon pea from various districts (a) macronutrients (b) micronutrients. 
of $\mathrm{K}$ in different sites. The reported level of potassium acceptable limit set by FAO, (2012) was $110 \mathrm{mg} / \mathrm{Kg}$ [52]. This was in agreement with the present study result.

Calcium: As shown in Table 6, the concentration of calcium in pigeon pea seed of different locations was ranged from $7.35-12.27 \mathrm{mg} / \mathrm{Kg}$. The highest level of calcium was observed in the AA $(12.27 \mathrm{mg} / \mathrm{Kg})$ whereas the least amount was found in SZ. Singh et al. (2018) reported that the mean concentration of pigeon pea ranged in $89.5 \mathrm{mg} / 100 \mathrm{~g}-118.6 \mathrm{mg} / 100 \mathrm{~g}$ [53]. Kunyanga et al. (2013) reported $(80.5 \mathrm{mg} / 100 \mathrm{~g})$ [54], Foodnet (2002) reported $(120.8 \mathrm{mg} / \mathrm{Kg})$ [55]. which were in good agreement with the results of this study but Nwokolo, 2010 reported $(150 \mathrm{mg} / \mathrm{Kg})$ [50], was higher than the results of pigeon pea collected from different locations. The variations in concentration and order of accumulated metals were different in the samples probably influenced by the difference in locations in relation to soil $\mathrm{pH}$ [56]. The FAO (2012) limit set was $55 \mathrm{mg} / 100 \mathrm{~g}$ [52], this is slightly lower than the results of the study area.

Magnesium: The mean concentration level of $\mathrm{Mg}$ varies from 8.95 to 12.67 $\mathrm{mg} / \mathrm{Kg}$ dry weight pigeon pea samples in various locations. Significantly different magnesium concentrations were observed in pigeon pea samples with various treatments. The highest concentration was found in pigeon pea collected from AA whereas the least amount observed in SZ. From literatures, [51] [52] [54] [55] [57] were reported the mean concentration of pigeon pea seed 14.1, 9.0, 10.8, 12.2 and 7.9 respectively. According to USDA (2016), the National Nutrient database, the report level of $\mathrm{Mg} 18.3 \mathrm{mg} / \mathrm{Kg}$, was higher than the results of the present study [58]. The Permissible limit set by FAO, (2012) was $9.6 \mathrm{mg} / \mathrm{Kg}$ [52] that is in agreement with the values of the present study.

Iron: In the study area, the iron content of pigeon pea samples ranged from 0.247 to $0.543 \mathrm{mg} / \mathrm{Kg}$ dry weight. The mean concentration of iron was found to be highest at SZ $(0.543 \mathrm{mg} / \mathrm{Kg})$ and a low amount of iron was found in AA $(0.247 \mathrm{mg} / \mathrm{Kg})$. The reason behind this was related to the increase in acidity of the soil. The literature values in pigeon pea from different workers: Abiola et al. (2019) were reported $1.02 \mathrm{mg} / 100 \mathrm{~g}$ [57], Kunyanga et al. (2013) (5.6 mg/100g) [54], Singh et al. (2018) reported $5 \mathrm{mg} / 100 \mathrm{~g}$ [53], Nwokolo (2010) $(3.9 \mathrm{mg} / 100 \mathrm{~g})$ [50] and Foodnet (2002) $(2.9 \mathrm{mg} / 100 \mathrm{~g})$ [55]. These were similar to the records of the current study. The permissible limit set by FAO (2012) in edible plants was $5.23 \mathrm{mg} / 100 \mathrm{~g}$ [52], which was in agreement with the present study.

Zinc: The concentration of zinc determined in pigeon pea samples (Table 7, Figure 1) was from 0.122 to $0.313 \mathrm{mg} / \mathrm{Kg}$ dry weight. The highest level of zinc was observed in SZ $(0.313 \mathrm{mg} / \mathrm{Kg})$ samples and the lowest level of zinc was determined in AA $(0.122 \mathrm{mg} / \mathrm{Kg})$. The reason may be due to the higher leaching of base-forming cations and increasing acidity of the soil. As reported by [59] [60], the mean concentration of $\mathrm{Zn}$ was ranged from $0.08 \mathrm{mg} / \mathrm{Kg}$ to $0.36 \mathrm{mg} / \mathrm{Kg}$; $\mathrm{Ku}$ nynga et al. (2013) reported $0.27 \mathrm{mg} / \mathrm{Kg}$ of $\mathrm{Zn}$ in pigeon pea [54]. Similar study by Foodnet (2002) reported $0.24 \mathrm{mg} / \mathrm{Kg}$ mean concentration of $\mathrm{Zn}$ in pigeon pea 
[55]. These were in good agreement with the recorded value of the present study. Abiola et al. (2019) was reported $(0.48 \mathrm{mg} / \mathrm{Kg})$ [57]; which was slightly higher than this study. The permissible limit of zinc in edible plants set by FAO, (2012) and USDA, (2016) was $0.274 \mathrm{mg} / \mathrm{Kg}$ and $0.276 \mathrm{mg} / \mathrm{Kg}$ respectively [52] [58], which was similar to the current study.

Manganese: As shown in Table 7, manganese content ranged from 0.061 $\mathrm{mg} / \mathrm{Kg}$ to $0.432 \mathrm{mg} / \mathrm{Kg}$. The highest manganese content was observed in SZ $(0.432 \mathrm{mg} / \mathrm{kg})$ and the lowest content was found in AA $(0.061 \mathrm{mg} / \mathrm{Kg})$ due to the increase in pH of soil. As reported by Foodnet (2002) the manganese mean concentration was $0.92 \mathrm{mg} / \mathrm{Kg}$ [55]; Singh (2018) reported $0.5 \mathrm{mg} / \mathrm{Kg}$ [53]. These were higher than the results obtained in this study. Abiola et al. (2019) were reported $0.138 \mathrm{mg} / \mathrm{Kg}$ [57]; Rajni and Vikas (2016) reported (0.069) [51]. This was satisfactorily agreed with this study.

Copper: The mean concentration of copper (Table 7, Figure 1) in this study was ranged from 0.08 to $0.13 \mathrm{mg} / \mathrm{Kg}$ dry weights in Pigeon pea samples. The relatively highest level of copper was found in ST $(0.13 \mathrm{mg} / \mathrm{Kg})$ samples and the least was for that of AA $(0.08 \mathrm{mg} / \mathrm{Kg})$ samples due to the variation in acidity and a textural class of soil. From the literature, Foodnet (2002) reported (0.13 $\mathrm{mg} / \mathrm{Kg}$ ) [55]; Rajni and Vikas (2016) reported $(0.12 \mathrm{mg} / \mathrm{Kg})$ [51], and Saxena (2010) reported $0.13 \mathrm{mg} / \mathrm{Kg}$ [59]. These were similar to the results recorded in different locations. The permissible limit set by FAO (2012) in edible plants was $1.2 \mathrm{mg} / 100 \mathrm{~g}[52]$.

Chromium: The chromium content of pigeon pea samples in this study was 0.0011 to $0.0019 \mathrm{mg} / \mathrm{Kg}$ dry weight in the pigeon pea sample. From the result, the highest level of chromium was recorded in $\mathrm{SZ}(0.0019 \mathrm{mg} / \mathrm{Kg})$ and the lowest was found at AA $(0.0011 \mathrm{mg} / \mathrm{Kg})$. The difference between samples based on locations was very small. This may be due to the availability of chromium metals in various soil types and characteristics [61]. As reported by Rajni and Vikas (2016), the chromium concentration was $0.001 \mathrm{mg} / \mathrm{Kg}$ [51]. According to Jabeen et al. (2010), the chromium content in pigeon pea seed was $0.19 \mu \mathrm{g} / \mathrm{g}$ [62]. Pigeon pea seed contains minute amounts of chromium which is required in very small amounts in the body for the regulation of blood sugar and transport of glucose into the cells [63].

\subsection{Determination of Proximate Composition in Pigeon Pea Sample}

The proximate contents such as protein, fats, carbohydrates, moisture, ash, crude fiber, and energy values were given in Table 8 and Table 9 as gm/Kg of seeds.

\section{Crude protein content}

As shown in Table 8, the average protein content of pigeon pea was ranged from $(19.28 \%-25.79 \%)$. The highest crude protein was found to be $25.79 \%$ at AA, and the lowest mean concentration was observed at ST (19.28\%). The level of crude protein in pigeon pea of AA was significantly different $(\mathrm{p}<0.05)$ from ST and SZ. This may be attributable to agroecology, soil type, and fertilizer 
Table 8. The mean concentration (mean \pm SD) of proximate composition of pigeon pea samples.

\begin{tabular}{ccccc}
\hline Districts & Crude Protein & Crude fat & carbohydrate & Moisture \\
\hline AA & $25.79^{\mathrm{a}} \pm 1.2$ & $0.993^{\mathrm{d}} \pm 0.05$ & $54.36^{\mathrm{d}} \pm 0.47$ & $13.05^{\mathrm{bac}} \pm 0.65$ \\
DW & $22.5^{\mathrm{c}} \pm 0.33$ & $1.6^{\mathrm{ac}} \pm 0.02$ & $57.35^{\mathrm{bc}} \pm 0.24$ & $12.6^{\mathrm{bc}} \pm 0.26$ \\
HW & $21.59^{\mathrm{d}} \pm 0.63$ & $1.62^{\mathrm{bac}} \pm 0.04$ & $58.53^{\mathrm{b}} \pm 0.25$ & $12.3^{\mathrm{c}} \pm 0.2$ \\
ST & $19.28^{\mathrm{f}} \pm 0.67$ & $1.72^{\mathrm{ba}} \pm 0.09$ & $57.54^{\mathrm{bc}} \pm 0.27$ & $13.73^{\mathrm{a}} \pm 0.31$ \\
SZ & $20.3^{\mathrm{e}} \pm 0.1$ & $1.56^{\mathrm{c}} \pm 0.05$ & $57.43^{\mathrm{bc}} \pm 0.2$ & $13.3^{\mathrm{ba}} \pm 0.53$ \\
Ho & $21.27^{\mathrm{d}} \pm 0.13$ & $1.75^{\mathrm{a}} \pm 0.2$ & $60.1^{\mathrm{a}} \pm 0.23$ & $10.65^{\mathrm{d}} \pm 0.73$ \\
TT & $23.21^{\mathrm{b}} \pm 0.72$ & $1.57^{\mathrm{bc}} \pm 0.03$ & $57.04^{\mathrm{c}} \pm 0.32$ & $12.33^{\mathrm{bc}} \pm 0.31$ \\
CV & 2.87 & 5.71 & 4.97 & 3.71 \\
LSD & 1.135 & 0.154 & 0.941 & 0.82 \\
\hline
\end{tabular}

${ }^{*}$ Means with the same letter are not significant, CV $=$ coefficient of variance, LSD = least significant difference.

application difference depending on farmers [64]. According to Vasave (2003), Aparna (2004), Pawar et al. (2009) and Oke (2014), the reported level was ranged from $17.97 \%$ - 26.38\% [65] [66] [67] [68]. These were relatively similar to those recorded in the present study. According to John (2005), the percent crude protein of commonly grown pigeon pea was in the range between $18 \%-26 \%$ [69]. Similarly, Sharma et al. (2011) reported (2\% - 22\%) [64], and Kachare et al. (2017) reported (17.62\% - 25.45\%) [70], these were all in good agreement with the results obtained in the present study. The permissible level of crude protein in pigeon pea recommended by $\mathrm{FAO}, 2016$ was $22.3 \%$.

\section{Crude fat content}

As depicted in Table 8, the crude fat ranged from $0.993 \%$ to $1.75 \%$. From the result, maximum crude fat was found in Ho and the least average content of fat was recorded at AA (0.993\%). The percent crude fat of pigeon pea of this study was comparatively lower than the fat percentage $(2.77 \%, 2.74 \%, 4.78 \%, 3.68 \%)$ reported by [54] [68] [71] [72] respectively. Eltayeb et al. (2010), and Sharma et al. (2011) reported $12 \%$, and $1.7 \%$ crude fat respectively [73] [64], and John (2005) reported the crude fat content in ranges between $1.2 \%-8.1 \%$ [69]. (USDA, 2016) database report was $1.49 \%$ [58]. These were similar to the results of the present study.

\section{Carbohydrate content}

The total carbohydrate content of pigeon pea under investigation was ranged between $54.36 \mathrm{mg} / 100 \mathrm{~g}$ to $60.10 \mathrm{mg} / 100 \mathrm{~g}$. The maximum carbohydrate content was observed in the Ho $(60.10 \mathrm{mg} / 100 \mathrm{~g})$ and the lowermost value was found at AA $(54.36 \mathrm{mg} / 100 \mathrm{~g})$. The Mean carbohydrate content in pigeon pea from Ho was significantly $(\mathrm{p}<0.05)$ higher than the rest. This may be related to the soil $\mathrm{pH}$ textural class, and change in the agroecology of study areas. Saxena (2010) reported $57.6 \mathrm{mg} / 100 \mathrm{~g}$ [59], Oke (2014), Olalekan and Bosede (2010), Adamu and Oyetunde (2013), Kunyanga et al. (2013) were reported between 51.4\% - 
58.8\% [54] [68] [71] [72]. These were in good agreement with the results of this study. The permissible level of carbohydrate in pigeon pea recommended by FAO was $60.4 \%$. These were in good agreement with the results obtained by the current study.

\section{Moisture content}

The data (Table 8) revealed that moisture contents varied from $10.65 \%$ to $13.73 \%$ in various locations. The highest moisture content $(13.73 \%)$ was found at ST and least at Ho (10.65\%). Analysis of variance showed that the level of moisture content was significantly different among districts, $(\mathrm{p}<0.05)$. Oke, (2014) and Eltayeb et al. (2010) were reported $11.2 \%$ and $11.7 \%$ respectively [68] [73]. These were in good agreement with those recorded in the present study. Olalekan and Bosede, (2010) reported 8.45\% moisture contents in pigeon pea [71]. This was comparatively lower than the results recorded in this study. The permissible level of moisture in pigeon pea recommended by FAO, (2012) was $10.8 \%[52]$.

\section{Ash contents}

Ash contents of pigeon pea of the study area were ranged between $(3.75 \%$ 5.31\%). Maximum Ash content was found in ST (5.31\%) and minimum content in AA (3.75\%). Oke, (2014), Adamu and Oyantunde, (2013) reported 8.22\%, and 9.93\% respectively [68] [72]. These were relatively higher than those recorded in the present study. However, [54] [71] [73] reported 3.58\%, 4.58\%, and 3.2\% ash content of pigeon pea respectively. The permissible level of ash in pigeon pea recommended by FAO was 3.8\%. It was in agreement with the current investigation.

\section{Crude fiber}

The results presented in Table 9 revealed that the crude fiber content of pigeon pea was ranged from $2.28 \%$ to $3.06 \%$ in the study districts. The highest value was found in AA (3.06\%) and the smallest was recorded in SZ (2.26\%). The content of crude fiber in pigeon pea seed was significantly different $(p<0.05)$.

Table 9. The mean concentration (mean \pm SD) of proximate composition of pigeon pea samples.

\begin{tabular}{cccc}
\hline Districts & Ash & Fiber & Energy \\
\hline AA & $3.75^{\mathrm{d}} \pm 0.39$ & $3.06^{\mathrm{a}} \pm 0.06$ & $330.54^{\mathrm{d}} \pm 1.56$ \\
DW & $4.39^{\mathrm{bc}} \pm 0.29$ & $2.91^{\mathrm{b}} \pm 0.02$ & $332.4^{\mathrm{c}} \pm 1.24$ \\
HW & $4.23^{\mathrm{bcd}} \pm 0.33$ & $2.73^{\mathrm{c}} \pm 0.05$ & $335.06^{\mathrm{b}} \pm 2.6$ \\
ST & $5.31^{\mathrm{a}} \pm 0.26$ & $2.41^{\mathrm{e}} \pm 0.02$ & $326.8^{\mathrm{f}} \pm 0.89$ \\
SZ & $4.77^{\mathrm{ba}} \pm 0.32$ & $2.26^{\mathrm{f}} \pm 0.012$ & $328.48^{\mathrm{e}} \pm 0.9$ \\
Ho & $3.95^{\mathrm{cd}} \pm 0.08$ & $2.28^{\mathrm{f}} \pm 0.02$ & $345.23^{\mathrm{a}} \pm 1.1$ \\
TT & $4.2^{\mathrm{bcd}} \pm 0.54$ & $2.65^{\mathrm{d}} \pm 0.01$ & $335.13^{\mathrm{b}} \pm 2.3$ \\
CV & 5.81 & 2.08 & 4.7 \\
LSD & 0.597 & 0.059 & 0.487 \\
\hline
\end{tabular}

${ }^{\star}$ Means with the same letter are not significant. 
Kunyunga et al. (2013), Adamu and Oyentunde, (2013) and Saxena, (2010) were reported higher content $(6.98 \%, 6.6 \%$ and $5.54 \%$ respectively) of fiber in pigeon pea [54] [59] [72]. John (2005), Oke (2014), and Eltayeb et al. (2010) were reported the Crude fiber content between $(1.2 \%$ - 8.1\%) in pigeon pea [68] [69] [73]. These were similar results and in good agreement with the current study. The permissible level of crude fiber in pigeon pea recommended by FAO, (2008) was $1.5 \%$ [74].

\section{Energy content}

As presented in Table 9, the average energy content of pigeon pea in the study districts was in the range of 326.8 - $345.23 \mathrm{Kcal} / \mathrm{g}$. The highest energy content was found in Ho $(345.23 \mathrm{Kcal})$ district and the least mean energy content was obtained at ST (326.8 Kcal/g). According to the report by [57] [68] [75], the mean energy content in pigeon pea was 298.25 , 334.3, and $304.3 \mathrm{Kcal} / \mathrm{g} \mathrm{respec}$ tively. These were in good agreement with the current study. FAO (2016) recommended the level of energy was $358.8 \mathrm{Kcal} / \mathrm{g}$ [4].

\section{Conclusion}

The study revealed that the concentrations of selected metals ( $\mathrm{K}, \mathrm{Mg}, \mathrm{Ca}, \mathrm{Fe}, \mathrm{Zn}$, $\mathrm{Mn}, \mathrm{Cu}$, and $\mathrm{Cr}$ ) were determined in pigeon pea seed and the metal $\mathrm{Cd}$ was found to be below the method detection limit in all districts. The highest concentration of $\mathrm{K}, \mathrm{Ca}$, and $\mathrm{Mg}$ were found in pigeon pea seed at Abela abaya (AA) and lowest at Sodo zuria (SZ) due to higher soil $\mathrm{pH}$ and a textural class of soils of AA while the concentration of $\mathrm{Fe}, \mathrm{Zn}, \mathrm{Mn}, \mathrm{Cu}$, and $\mathrm{Cr}$ were high in the pigeon pea at SZ. The proximate analysis result indicated that pigeon pea was a good source of protein, carbohydrate, energy but low-fat content. The ANOVA at a $95 \%$ confidence level suggested that there was a significant difference in the mean concentration of selected metals and nutritional values in different locations. Physicochemical properties in various locations elucidate the soils of the study area are suitable for the production of pigeon pea. The results of this study suggest that these cereal plants are safe to be utilized as a staple food since the concentration of metals and nutritional values are within the recommended limits of FAO and WHO guidelines.

\section{Availability of Data and Materials}

We declare that the data and materials presented in this manuscript can be made available as per the editorial policy of the journal.

\section{Acknowledgments}

We would like to acknowledge Wolaita Sodo University and Arbaminch University department of chemistry for providing the necessary resources.

\section{Conflicts of Interest}

The authors declare no conflicts of interest regarding the publication of this paper. 


\section{References}

[1] Mergeai, G., Kimani, P., Mwang'ombe, A., Smith, C. and Audi, P. (2001) Survey of Pigeonpea Production Systems, Utilization and Marketing in Semi-Arid Lands of Kenya. Biotechnology and Agronomy, Society and Environment, 5,145-153.

[2] Ecocrop (2016) Ecocrop Database. FAO, Rome, Italy.

[3] Mallikarjuna, N., Saxena, K.B., Varshney, R., Senthilvel, S., Jadhav, D.R. (2012) Differences between Cajanus cajan (L.) Millspaugh and C. cajanifolius van der Maesen, The Progenitor Species of Pigeonpea. Genet Resource and Crop Evolution, 59, 411-417. https://doi.org/10.1007/s10722-011-9691-8

[4] FAO (Food and Agricultural Organization). (2016) FAOSTAT Food and Agriculture Organization of the United Nations, Rome, Italy.

[5] Emefiene, M.E., Joshua, V.I., Nwadike, C., Yaroson, A.Y. and Zwalnan N.D.E. (2014) Profitability Analysis of Pigeon Pea (Cajanus cajan) Production in Riyom LGA of Plateau State. International Letters of Natural Sciences, 18, 73-88. https://doi.org/10.18052/www.scipress.com/ILNS.18.73

[6] Shanower, T.G., Romeis, J. and Minja, E.M. (1999) Insect Pests of Pigeon Pea and their Management. Annual Review of Entomology, 44, 77-96.

https://doi.org/10.1146/annurev.ento.44.1.77

[7] Speranza, C.I., Kiteme, B. and Wiesmann, U. (2007) Droughts and Famines: the Underlying Factors and the Causal Link among Agro-Pastoral Households in Semi-Arid Makueni District, Kenya. Global Environmental Change, 18, 220-233.

[8] Subbarao, G.V., Chauhan, Y.S. and Johansen, C. (2000) Patterns of Osmotic Adjustment in Pigeon Pea Its Importance as a Mechanism of Drought Resistance. European Journal of Agronomy, 12, 239-249. https://doi.org/10.1016/S1161-0301(00)00050-2

[9] Damaris, A.O. (2007) the Potential of Pigeon Pea (Cajanus cajan (L.) Millsp.) in Africa. Natural Resources Forum, 31, 297-305. https://doi.org/10.1111/j.1477-8947.2007.00157.x

[10] Pelletier, D.L., Frongillo, E.A., Schroeder, D.G. and Habicht, J.P. (1995) The Effect of Malnutrition on Child Mortality in Developing Countries. Bulletin of the World Health Organization, 3, 443-448.

[11] FAO (Food and Agriculture Organization of the United Nation) (2010) Livelihood Systems in Dry lands in the Context of Climate Change Inventory of Adaptation Practices and Technologies of Ethiopia, Rome.

[12] Simtowe, F., Muange, E., Munyua, B. and Diagne, A. (2012) Technology Awareness and Adoption: The Case of Improved Pigeon Pea Varieties in Kenya. International Association of Agricultural Economists (IAAE) Triennial Conference, Brazil, January 2012, 18-24.

[13] Lose, S.J., Hilger, T.H., Leihner, D.E. and Kroschel, J. (2003) Cassava, Maize and Tree Root Development as Affected by Various Agroforestry and Cropping Systems in Benin. Agriculture, Ecosystems and Environment, 100, 137-151. https://doi.org/10.1016/S0167-8809(03)00182-8

[14] Apostoli, P. (2002) Elements in Environmental and Occupational Medicine. Journal of Chromatography, 778, 63-97. https://doi.org/10.1016/S0378-4347(01)00442-X

[15] Antoine, J.M., Fung, L.H., Grant, C.N., Dennis, H.T. and Lalor, G.C. (2012) Dietary Intake of Minerals and Trace Elements in Rice on the Jamaican Market. Journal Food Composition and Analysis, 26, 111-121. https://doi.org/10.1016/j.jfca.2012.01.003 
[16] Birhanu, M. (2015) Levels of Selected Essential and Non-Essential Metals in Pigeon Pea Seeds. Brazilian Journal of Food Technology, 18, 102-111. https://doi.org/10.1590/1981-6723.5614

[17] Ashenef, A. (2014) Essential and Toxic Metals in Tea (Camellia sinensis) Imported and Produced in Ethiopia. Food Additives and Contaminants: Part B Surveillance, 7, 30-36. https://doi.org/10.1080/19393210.2013.831951

[18] EIAR (Ethiopian Institute of Agricultural Research) (2016) Fifteen Years (2016-2030) National Lowland pulses research strategy, Addis Abeba, Ethiopia.

[19] Birhanu, K. (2012) Market Access and Value Chain Analysis of Dairy Industry in Ethiopia: The Case of Wolaita Zone. Ph.D. Dissertation, Haramaya University, Ethiopia.

[20] Okalebo, J.R., Gathua, K.W. and Woomer, P.L. (2002) Laboratory Methods of Soil and Plant Analysis. 2nd Edition, Sacred African Publisher, Nairobi.

[21] Carter, D.C. (1993) Soil Sampling and Methods of Analysis. CRC Press, Florida, 823.

[22] Van Reeuwijk, L.P. (1992) Procedures for Soil Analysis. 3rd Edition, International Soil Reference and Information Center (ISRIC), Wageningen, Netherland.

[23] Nielsen, S.S. (2010) Food Analysis. 4th Edition, Department of Food Science Purdue University West Lafayette, 108-191. https://doi.org/10.1007/978-1-4419-1478-1

[24] Olsen, S.R., Cole, C.V., Watanabe, F.S. and Dean, L.A. (1954) Estimation of Available Phosphorus in Soils by Extraction with Sodium Bicarbonate. Department of Agriculture, USA.

[25] Bremner, G.M. and Mulvaney, C.S. (1982) Nitrogen. In: Black, C.A., Ed., Methods of Soil Analysis, American Society of Agronomy Inc., Madison, 1149-1148.

[26] Day, P.R. (1965) Hydrometer Method of Particle Size Analysis. In: Black, C.A., Ed., Methods of Soil Analysis, American Society of Agronomy, Madison, 562-563.

[27] Huang, L., Bell, R.W., Dell, B. and Woodward, J. (2004) Rapid Nitric Acid Digestion of Plant Material with an Open Vessel Microwave System. Common Soil Science Plant Analysis, 35, 427-440. https://doi.org/10.1081/CSS-120029723

[28] Okwu, D.E. and Morah, F.N. (2004) Mineral and Nutritive Value of Dennettia Tripetala Fruits. Fruits, 59, 437-442. https://doi.org/10.1051/fruits:2005006

[29] Mustafa, S., Hakan, C., Mustafa, T. and Orhan, T. (2006) Comparison of Digestion Procedures on Commercial Powdered Soup Samples for the Determination of Trace Metal Contents by Atomic Absorption Spectrometry. Journal of Food and Drug Analysis, 14, 62-67.

[30] Demirel, S., Tuzen, M. and Soylak, M. (2008) Evaluation of Various Digestion Procedures for Trace Element Contents of Some Food Materials. Journal of Hazardous Materials, 152, 102-120. https://doi.org/10.1016/j.jhazmat.2007.07.077

[31] Dean, J.R. (2003) Methods for Environmental Trace Analysis. John Wiley \& Sons, Hoboken. https://doi.org/10.1002/0470863250

[32] Iqbal, J., Carney, W.A., La Caze, S. and Theegala, C.S. (2010) Metals Determination in Biodiesel by ICP-OES with Microwave Assisted Acid Digestion. The Open Analytical Chemistry Journal, 4, 18-26. https://doi.org/10.2174/1874065001004010018

[33] Brady, N. and. Weil, R. (2002) The Nature and Properties of Soils.13th Edition. Prentice-Hall Inc., Upper Saddle River, NJ.

[34] Abi, T., Gebrekidan, M. and Mesfin, B. (2015) Evaluation of Universal Extractants 
for Determination of Some Macronutrients from Soil. Communication in Soil Science and Plant Analysis, 29, 199-213.

[35] Jones, B.J. (2003) Agronomic Handbook: Management of Crops, Soils, and Their Fertility. CRC Press, New York. https://doi.org/10.1201/9781420041507

[36] Iwara, A.I., Gani, B.S., Adeyemi, J.A. and Ewa, E.E. (2013) Effect of Road Construction on Adjoining Soil Properties in Tinapa Resort, South-Southern Nigeria. Open Journal of Advanced Engineering Techniques, 1, 42-48.

[37] Barua, K. and Haque, M. (2013) Soil Characteristics and Carbon Sequestration Potentials of Vegetation in Degraded Hills of Chittagong Bangladesh. Land Degradation and Development, 24, 63-71. https://doi.org/10.1002/ldr.1107

[38] Deshmukh, K. (2012) Studies on Chemical Characteristics and Classification of Soils from sangamner Area, Maharastra. Rasayan. Journal of Chemistry, 5, 74-85.

[39] Landon, J.R. (1991) Booker Tropical Soil Manual. A hand Book for Soil Survey and Agricultural Land Evaluation in the Tropics and Sub-Tropics. Longman, New York.

[40] Bulluck, L.R., Brosius, M. and Evanylo, G.K. (2002) Organic and Synthetic Fertility Amendments Influence Soil Microbial, Physical and Chemical Properties on Organic and Conventional Farms. Applied Soil Ecology, 19, 147-160. https://doi.org/10.1016/S0929-1393(01)00187-1

[41] Chang, R. (2000) Physical Chemistry for the Chemical and Biological Sciences. University Science Books, Sausalito, 234-277.

[42] Tekalign, T. (1991) Soil, Plant, Water, Fertilizer, Animal Manure and Compost Analysis. Working Document No. 13, International Livestock Research Center for Africa, Addis Ababa.

[43] Amato, M., Gestal, V., Ladd, D. and Monrozier, J. (1990) Soil Microhabitats and Carbon and Nitrogen Metabolism. Soil Science, 3, 82-87.

[44] Chowdhury, M.A., Khairun, Y. and Rahman, M.M. (2011) Effect of Combined Shrimp and Rice Farming on Water and Soil Quality. Aquaculture International, 19, 1193-1206. https://doi.org/10.1007/s10499-011-9433-0

[45] Wakene, N. and Heluf, G. (2003) The Impact of Different Land Use Systems on Soil Quality of Western Ethiopian Alfisols. Bako Agricultural Research Center, West Shoa, Ethiopia.

[46] Vance, C.P., Stone, C.U. and Allan, D. (2003) Phosphorus Acquisition and Use: Critical Adaptation by Plants for Securing Non-Renewable Resources. New Phytologist, 15, 423-447. https://doi.org/10.1046/j.1469-8137.2003.00695.x

[47] Kumar, S., Iyer, A. and Agarwal, S. (2011) Cotton Yield in Relation to Physicochemical Properties of Cultivated Soil of Rajkot Region. International Journal of Advanced English Technology, 7, 123-164.

[48] Verma, V.K., Patel, L.B., Toor, G.S. and Sharma, P.K. (2005) Spatial Distribution of Macronutrients in Soils of Arid Tract of Punjab. International Journal of Agriculture \& Biology, 7, 370-372.

[49] Chaves, L.H., Estrela, M.A. and Souza, R. (2011) Effect on Plant Growth and Heavy Metal Accumulate on by Sun Flower. Journal of Phytology, 3, 4-9.

[50] Nwokolo, E. (2010) Nutritional Evaluation of Pigeon Pea Meal. Plant Foods in Human Nutrition, 37, 283-290. https://doi.org/10.1007/BF01092203

[51] Rajni, K. and Vikas, N. (2016) Proximate Composition, Nutritional Profile and Health Benefits of LEGUMES. Agricultural Research Communication Centre.

[52] FAO (2012) The Food and Agriculture Organization of the United Nations higher 
plants. Russian Journal of Plant Physiology, 53, 257-277.

[53] Singh, S., Jadhav, P. and Nadanwar, R. (2018) Assessment of Nutritional Quality Parameters in Selected Vegetable Type Pigeon Pea Genotypes. Journal of Pharmacoognosy and Phytochemistry, 1, 1446-1450.

[54] Kunyanga, C., Imungi, J. and Vellingiri, V. (2013) Nutritional Evaluation of Indigenous Foods with Potential Food-Based Solution to Alleviate Hunger and Malnutrition in Kenya. Journals of Applied Biological Science, 67, 5277-5288.

https://doi.org/10.4314/jab.v67i0.95049

[55] Foodnet, (2002) R-Directory of Commodities: Pigeon Pea. http://www.foodnet.cgiar.org/market/Tropcomm/part2R/htm

[56] Frossard, E., Bucher, M.M., Achler, F., Mozafar, A. and Hurrell, R. (2000) Potential for Increasing the Content and Bioavailability of $\mathrm{Fe}, \mathrm{Zn}$ and $\mathrm{Ca}$ in Plants for Human Nutrition. Journal of Science Food and Agriculture, 80, 861-879. https://doi.org/10.1002/(SICI)1097-0010(20000515)80:7<861::AID-JSFA601>3.0.CO $\underline{; 2-\mathrm{P}}$

[57] Abiola, T. (2019) Protein Quality and the Biological Value of Raw and Cooked Pigeon Pea (Cajanus cajan) Seeds. EC Nutrition, 14, 218-226.

[58] USDA (United States Department of Agriculture) (2016) National Nutrient Data Base for Standard Reference, Release 28. Agricultural Research Service, USA.

[59] Saxena, K. B. (2010) Prospects of Pigeon Pea Hybrids in Indian Agriculture. Electronic Journal of Plant Breeding, 1, 1107-1117.

[60] Patil, H.E., Intwala, C.G., Patel, J.V. and Lakhote, S.J. (2015) Genetic Improvement of Vegetable Type Pigeon Pea (Cajanus cajan L.). National Academy of Agricultural Science, 33, 2809-2813.

[61] Arain, M.B., Kazi, T.G., Baig, J.A. and Sarfraz, R.A. (2009) Determination of Arsenic Levels in Lake Water, Sediment and Food Stuff from Selected Area of Sindh, Pakistan. Food Chemistry and Toxicology, 47, 242-248.

https://doi.org/10.1016/j.fct.2008.11.009

[62] Jabeen, S., Shah, M.T., Khan, S. and Hayat, M.Q. (2010) Determination of Mjor and Race Elements in Ten Important Folk Therapeutic Plants of Haripur basin. Journal of Medicinal Plants, 4, 559-566.

[63] Anderson, R.A. (2013) Nutritional Factors Influencing the Glucose/Insulin System: Chromium. Journal of the American College of Nutrition, 16, 404-410.

[64] Sharma,S., Agarwal, N. and Verma, P. (2011) A Hidden Treasure of Regime Nutrition. Journal of Functional and Environmental Botany, 2, 91-101. https://doi.org/10.5958/j.2231-1742.1.2.010

[65] Vasave, G.K. (2003) Nutritional Evaluation of Grains and Leaf Nitrate Reductase Potential of Some Pigeon Pea Genotypes. M.Sc. Thesis, Maharashtra University, India.

[66] Aparna, K. (2004) Evaluation of Proximate Composition of Grains and Leaf Nitrate Reductase Activity in Different Maturity Group Pigeon Pea Cultivars. M.Sc. Thesis, Indian National Agricultural Research System.

[67] Pawar, V., Munjal, S., Satbhai, R. and Mulla, M. (2009) Proximate Composition and Limiting Amino Acids Content in Grain of Three Maturity Groups of Pigeon Pea Genotypes at Different Sowing Dates. Legume Research, 32, 86-91.

[68] Oke, D.G. (2014) Proximate and Phytochemical Analysis of Pigeon Pea (Cajanus cajan) Leaves. Chemistry of Science and Transformation, 3, 1172-1178. 
[69] John, H. (2005) Principles of Food Crop Production. Journal of Food Science, 3, 35-42.

[70] Kachare, D.P., Satbhai, R.D., Rathod, D.B. and Naik, R.M. (2017) Evaluation of Pigeon Pea (Cajanus cajan L.) Genotypes for Nutritional Quality. Agricultural Research Communication Center. https://doi.org/10.18805/LR-3899

[71] Olalekan, A.J. and Bosede, B.F. (2010) Comparative Study on Chemical Composition and Functional Properties of Three Nigerian Legumes (Jack Beans, Pigeon Pea and Cowpea).

[72] Adamu, A. and Oyetunde, J. (2013) Comparison of Dietary Proximate and Mineral Values of Two Varieties of Bean. Asian Journal of Natural \& Applied Sciences, 2, 103-106.

[73] Eltayeb, A.R., Ali, A.O. and Haron, R. (2010) The Chemical Composition of Pigeon Pea (Cajanus cajan) Seed and Functional Properties of Protein Isolate. Pakistan Journal of Nutrition, 9, 1069-1073.

[74] FAO (2008) The Food and Agriculture Organization of the United Nations Higher Plants. Russian Journal of Plant Physiology, 53, 257-277.

[75] Rama, V. and Nirmala, K. (2017) By-Products as Potent Natural Resource to Produce Protein Rich Edible Food. International Journal of Current Agricultural Sciences, 7, 229-236. 